\title{
TOTAL AND PARTICULATE CONTENTS AND VERTICAL STRATIFICATION OF ORGANIC CARBON IN AGROFORESTRY SYSTEM IN CAATINGA ${ }^{1}$
}

\author{
BRUNA DE FREITAS IWATA², MARIA LETÍCIA STEFANY MONTEIRO BRANDÃO²*, REGIS DOS SANTOS \\ BRAZ $^{3}$, LUIZ FERNANDO CARVALHO LEITE ${ }^{4}$, MIRIAN CRISTINA GOMES COSTA ${ }^{5}$
}

\begin{abstract}
The objective of this work was to evaluate the variation in total and particulate organic carbon contents, carbon vertical stratification, and sensitivity index of organic matter fractions in soils with organic residues arranged in alleys in an agroforestry system, with and without use of fire, in the Caatinga biome, in Brazil. The experiment was conducted in a split-plot arrangement with four replications, with the factor fire in the plots, and the factor organic residues in the subplots. The organic residues used consisted of Gliricidia sepium plants; G. sepium plants and carnauba processing residue; G. sepium plants and bio-compost; and $G$. sepium plants, carnauba processing residue, and bio-compost, which were evaluated in three soil layers. The alleys with carnauba processing residue, $G$. sepium plants, and bio-compost presented a better maintenance of particulate, and mineral-associated organic carbon contents. Thus, the agroforestry management in alleys using these three residues was efficient for the maintenance of labile and recalcitrant organic matter compartments. Particulate organic carbon was more sensitive to changes in soil management than total organic matter content, in all alleys, presenting higher sensitivity indexes.
\end{abstract}

Keywords: Organic fertilizer application. Carbon fractions. Soil quality.

\section{CARBONO ORGÂNICO TOTAL E PARTICULADO E RELAÇÃO DE ESTRATIFICAÇÃO EM SISTEMAS AGROFLORESTAIS NA CAATINGA}

RESUMO - O objetivo deste trabalho foi avaliar a variação no carbono orgânico total e particulado, relação de estratificação de C, e índice de sensibilidade dessas frações da MOS sob resíduos orgânicos em aléias em um sistema agroflorestal, com e sem uso do fogo na Caatinga. Por meio de experimento em parcelas subdivididas com quatro repetições, onde nas parcelas foi avaliado o fator fogo, e nas subparcelas foi avaliado o fator resíduos orgânicos nas aléias, com as variações de gliricídia isolada, gliricídia com bagana de carnaúba, gliricídia com biocomposto e gliricídia, bagana de carnaúba e biocomposto, sob três profundidades. Nas aléias com uso combinado dos resíduos da bagana de carnaúba, gliricídia e biocomposto houve maior conservação tanto do conteúdo de $\mathrm{C}$ orgânico particulado quanto do $\mathrm{C}$ associado aos minerais. Assim, o manejo agroflorestal em aléias utilizando a combinação dos três resíduos foi eficiente na conservação de uma matéria orgânica lábil e mais estável. Verificou-se também que o carbono orgânico particulado em todas as aléias foi mais sensível às modificações realizadas no manejo do solo em relação ao conteúdo total da MOS, no qual observou-se maiores índices de sensibilidade dessa fração.

Palavras-chave: Adubação orgânica. Frações físicas do carbono. Qualidade do solo.

\footnotetext{
${ }^{*}$ Corresponding author

${ }^{1}$ Received for publication in $07 / 12 / 2020$; accepted in $02 / 17 / 2021$.

Paper extracted from the doctoral thesis of the first author

${ }^{2}$ Instituto Federal do Piauí, Campus Teresina Central, Teresina, PI, Brazil; iwata@ifpi.edu.br - ORCID: 0000-0002-6465-9731, marialeticia.gab@gmail.com - ORCID: 0000-0001-6488-1300.

${ }^{3}$ Padre Eliesio dos Santos Escola Família Agrícola, Ipueiras, CE, Brazil; regismta@gmail.com - ORCID: 0000-0002-2992-0623.

${ }^{4}$ Empresa Brasileira de Pesquisa Agropecuária, Centro de Pesquisa Agropecuária do Meio-Norte, Teresina, PI, Brazil; luiz.f.leite@embrapa.br; ORCID: 0000-0001-9648-705X.

${ }^{5}$ Universidade Federal do Ceará, Fortaleza, CE, Brazil; mirian.costa@ufc.br - ORCID: 0000-0002-4682-4756.
} 


\section{INTRODUCTION}

Soil managing results in important changes in organic matter contents; thus, soil carbon stocks are quality indicators for agricultural practices, because of its correlation with soil physical, chemical, and biological attributes (NANZER et al., 2019; ARAÚJO, 2019).

Studies have shown that total soil organic matter (SOM) contents are not a sensitive indicator to evaluate agroecosystems, since small changes in total carbon are difficult to detect in a short time, partly because the soil natural variability is high. Thus, increases or decreases in carbon contents in the SOM fractions enable a better measurement of changes caused by management systems. Therefore, the evaluation of different carbon compartments, mainly labile fractions, assists in understanding the dynamics of managed areas and possible paths of increasing and decreasing carbon processes (MOURA-BUENO, DALMOLIN, DIEGO, 2017).

The SOM fractionation shows the particulate organic carbon and mineral-associated organic carbon. High carbon stocks in clayey soils are due to the organo-mineral interaction between clay particles and functional groups of the SOM (LUZ, 2017; IWATA et al., 2012), which are more recalcitrant. However, short-time changes are detected through evaluations of the particulate fraction, which is the more labile part of the SOM, and the main cementing agent of organic matter in the soil aggregation process, mainly for macroaggregates (FERREIRA et al, 2019; MENEZES et al., 2017).

Another efficient and practical alternative to evaluate soil conservation is the vertical stratification of the organic carbon, which enables to compare the organic carbon contents of the surface layer with lower layers, and has been used as an indicator of soil quality (FERREIRA et al., 2012; MOURA et al., 2015; NANZER et al., 2019). A high stratification level of the SOM indicates a preserved, balanced, and high-quality soil in the surface layer, and improves water infiltration (MOURA et al., 2015).

Briedis et al. (2012) evaluated a no-tillage area in Ponta Grossa, Paraná, Brazil, and found that carbon increases in surface layers increase carbon stratification and are linearly correlated with the stratification level. Moreover, they found that the higher the stratification level, the higher the carbon cycling, which results in higher carbon sequestration by the soil. However, this kind of study for agroforestry systems in the Caatinga biome are practically nonexistent.

Considering that agriculture in the Semiarid region of Brazil is mainly practiced under conventional system with intensive use of fire for soil preparation, the search for conservationist systems, such as agroforestry systems, is emerging. It includes identification of efficient quality indicators for these soil management strategies, such as the diversification of the organic matter and crop species; increasing microbial biodiversity; and efficient use of water and space, which can base decision making for the improvement of agroecosystems.

In this context, the objective of this work was to evaluate the variation in total and particulate organic carbon contents, carbon vertical stratification, and sensitivity index of organic matter fractions in soils with organic residues arranged in alleys in an agroforestry system, with and without use of fire, in the Caatinga biome, in Brazil.

\section{MATERIAL AND METHODS}

\section{Location and characterization of the study area}

The study was conducted in Bela Cruz, state of Ceara, Brazil ( $3^{\circ} 00^{\prime} 39.29^{\prime \prime} \mathrm{S}, 40^{\circ} 13^{\prime} 30.38^{\prime \prime} \mathrm{W}$, and altitude of $50 \mathrm{~m})$. The experimental area encompassed a transitional zone with phytoecological characteristics of the coastal zone vegetational complex, within the Caatinga biome. It presented a slight wavy relief and a Typic Hapludult soils (Argissolo Vermelho Amarelo). The climate of the region is characterizing as tropical hot semiarid (BSh), according to the Köppen classification (ALVARES et al., 2014), with a rainy season from February to May, mean annual rainfall depth of $1,096.9 \mathrm{~mm}$ and mean temperatures of 18 to $30^{\circ} \mathrm{C}$. The mean temperature and rainfall depth rate in the study period, between April and June 2013, was $31^{\circ} \mathrm{C}$ and $4.0 \mathrm{~mm} \mathrm{day}^{-1}$, respectively.

\section{Soil managing and experimental design}

The agroforestry system was established in 2007 in an area of approximately one hectare $(110 \times$ $90 \mathrm{~m})$. After a selective cutting of the shrubarboreous vegetation, preserving two hundred native trees per hectare, the area was divided into two plots of 0.5 ha, one was subjected to a controlled fire and the other was maintained with pruning residues piled linearly in stacks of $0.5 \mathrm{~m}$ width, perpendicular to the area slope and spaced $3.0 \mathrm{~m}$ apart. An alley crop model was used, which consisted of two rows of Gliricidia sepium (Jacq.) Steud. plants with spacing of $0.5 \mathrm{~m}$ between rows and $0.5 \mathrm{~m}$ between plants. The legume G. sepium was used as soil green fertilizer, cashew (Anacardium occidental L.) trees were established as a permanent crop, and maize (Zea mays L.) and cowpea (Vigna unguiculata L. Walp) were the annual crops.

A completely randomized design with four replications was used. The treatments were arranged in split-plot, with the factor fire (with and without) in the plots and the factor organic residues in the subplots ( $G$. sepium plants - GSP; G. sepium plants and carnauba processing residue - GSP+CPR; 
G. sepium plants and bio-compost - GSP+BC; and G. sepium plants, carnauba processing residue, and biocompost - GSP $+\mathrm{CPR}+\mathrm{BC}$ ) (Table 1). Soil samples were collected from the $0-10,10-20$, and $20-40 \mathrm{~cm}$ layers for evaluation.

The G. sepium plants was pruned two times a year, in the rainy season. The shoot biomass (leaves and thin branches) was shredded to approximately 10 to $20 \mathrm{~cm}$ length and distributed on the soil of the alleys. The carnauba processing residue was applied over the whole area of the plots with this treatment at the rate of $16 \mathrm{Mg} \mathrm{ha}^{-1}$. The bio-compost (cashew leaves, caprine manure, and carnauba processing residue) was applied to the maize and cowpea crops at the rate of $116 \mathrm{~g} \mathrm{pit}^{-1}$, corresponding to $2.3 \mathrm{Mg} \mathrm{ha}^{-1}$.

Table 1. Treatments with organic residues used in an alley model, with and without use of fire in an agroforestry system in the Caatinga biome, Brazil.

\begin{tabular}{|c|c|c|}
\hline Treatments & Management & Organic residue \\
\hline GSP & \multirow{4}{*}{ With fire } & Gliricidia sepium plants \\
\hline $\mathrm{GSP}+\mathrm{BC}$ & & Gliricidia sepium plants and bio-compost \\
\hline $\mathrm{GSP}+\mathrm{CPR}$ & & Gliricidia sepium plants and carnauba processing residue \\
\hline $\mathrm{GSP}+\mathrm{CPR}+\mathrm{BC}$ & & Gliricidia sepium plants, carnauba processing residue, and bio-compost \\
\hline GSP & \multirow{4}{*}{ Without fire } & Gliricidia sepium plants \\
\hline $\mathrm{GSP}+\mathrm{BC}$ & & Gliricidia sepium plants and bio-compost \\
\hline $\mathrm{GSP}+\mathrm{CPR}$ & & Gliricidia sepium plants and carnauba processing residue \\
\hline $\mathrm{GSP}+\mathrm{CPR}+\mathrm{BC}$ & & Gliricidia sepium plants, carnauba processing residue, and bio-compost \\
\hline
\end{tabular}

\section{Carbon stocks}

The total organic carbon was determined by oxidation using potassium dichromate with external heat and titration with ammonium iron sulfate, according to the modified method of Yeomans and Bremner (1988). The total organic carbon stocks in each layer were determined by multiplying the total organic carbon in the sample by the soil density (volumetric ring method) and the layer thickness.

\section{Carbon fractionation}

The method described by Cambardella and Elliott (1992) was applied, using a $\mathrm{NaOH}$ solution as dispersant at 2:1 (soil:solution) and 15 minutes of shaking. The carbon in the soil fraction retained in the $53 \mu \mathrm{m}$ sieve was termed particulate organic carbon (POC). The mineral-associated organic carbon (MAOC) contents were obtained by subtracting the POC from the total organic carbon; MAOC is the carbon determined via wet oxidation (YEOMANS; BREMNER, 1988).

\section{Stratification level, sensitivity index, and statistics}

The stratification level was calculated as proposed by Franzluebbers (2002), by dividing the carbon content in the soil surface layer $(0-10 \mathrm{~cm})$ by the values in subsurface layers (10-20 and 20-40 $\mathrm{cm})$. The soil carbon contents of a control area (native Caatinga forest), adjacent to the experimental area (control) were used to determine the sensitivity index. The sensitivity index of the compartments of the soil organic matter was calculated according to Banger et al. (2010), using the formula:

Sensitivity index $=\frac{(\text { carbon fraction in the treatment }- \text { carbon fraction in the control) }}{\text { carbon fraction in the control }} \times 100$

The data of each parameter were subjected to analysis of variance (ANOVA) and the means were compared by the Tukey's test at 5\% probability level, using the program ASSISTAT 7.4 beta.

\section{RESULTS AND DISCUSSION}

The use of fire for soil preparation decreased the particulate organic carbon (POC) in the soil surface layers, up to $20 \mathrm{~cm}$, in most treatments, except for the treatment with $G$. sepium plants and bio-compost (GSP+BC) in the $0-10 \mathrm{~cm}$ and $10-20$ $\mathrm{cm}$ layers, and in the treatment with $G$. sepium plants, carnauba processing residue, and bio-compost $(\mathrm{GSP}+\mathrm{CPR}+\mathrm{BC})($ Table 2). However, the highest POC contents in the deepest layer evaluated (20-40 $\mathrm{cm}$ ) were found in the treatments with the use of fire (Table 2).

Moreover, after six years using soil preparation with fire, it was harmful for the more labile fractions of the soil organic matter (SOM), mainly in the surface layers. However, this deleterious effect was less intense when using organic residues containing bio-compost and carnauba processing residue. Therefore, the effect of fire is linked to several factors, such as type of organic residue (chemical-structural composition) and their effects on the dynamics of the soil biota. 
B. F. IWATA et al.

Table 2. Particulate organic carbon (POC), mineral-associated organic carbon (MAOC), and POC to MAOC ratio in a Typic Hapludult managed with organic residues and use of fire in an agroforestry system in the Caatinga biome, Brazil.

\begin{tabular}{|c|c|c|c|c|c|c|}
\hline \multirow{3}{*}{ Treatments } & \multicolumn{2}{|c|}{ POC } & \multirow{2}{*}{\multicolumn{2}{|c|}{ MAOC }} & \multirow{2}{*}{\multicolumn{2}{|c|}{$\begin{array}{c}\mathrm{POC} / \mathrm{MAOC} \\
(\%)\end{array}$}} \\
\hline & \multicolumn{2}{|c|}{$\mathrm{g} \mathrm{Kg}^{-1}$} & & & & \\
\hline & \multicolumn{6}{|c|}{$0-10 \mathrm{~cm}$} \\
\hline & With fire & Without fire & With fire & Without fire & With fire & Without fire \\
\hline GSP & $0.23 \mathrm{cB}$ & $0.28 \mathrm{bA}$ & $22.73 \mathrm{cA}$ & $19.45 \mathrm{bB}$ & $1.01 \mathrm{bB}$ & $1.43 \mathrm{aA}$ \\
\hline $\mathrm{GSP}+\mathrm{BC}$ & $0.29 \mathrm{abA}$ & $0.19 \mathrm{cB}$ & $23.02 \mathrm{cB}$ & $25.20 \mathrm{aAB}$ & $1.25 \mathrm{aA}$ & $0.75 \mathrm{cB}$ \\
\hline $\mathrm{GSP}+\mathrm{CPR}$ & $0.30 \mathrm{aB}$ & $0.47 \mathrm{aA}$ & $22.37 \mathrm{bA}$ & $25.92 \mathrm{aB}$ & $1.36 \mathrm{aB}$ & $1.81 \mathrm{bA}$ \\
\hline \multirow[t]{3}{*}{$\mathrm{GSP}+\mathrm{CPR}+\mathrm{BC}$} & $0.27 \mathrm{bB}$ & $0.39 \mathrm{abA}$ & $23.38 \mathrm{abA}$ & $25.54 \mathrm{aB}$ & $1.15 \mathrm{bB}$ & $1.52 \mathrm{bA}$ \\
\hline & \multicolumn{6}{|c|}{$10-20 \mathrm{~cm}$} \\
\hline & With fire & Without fire & With fire & Without fire & With fire & Without fire \\
\hline GSP & $0.18 \mathrm{cB}$ & $0.36 \mathrm{aA}$ & $21.41 \mathrm{bcA}$ & $18.79 \mathrm{cB}$ & $0.84 \mathrm{cB}$ & $1.91 \mathrm{aA}$ \\
\hline $\mathrm{GSP}+\mathrm{BC}$ & $0.31 \mathrm{aAB}$ & $0.29 \mathrm{abB}$ & $20.63 \mathrm{cA}$ & $20.90 \mathrm{bcA}$ & $1.50 \mathrm{abA}$ & $1.38 \mathrm{bA}$ \\
\hline $\mathrm{GSP}+\mathrm{CPR}$ & $0.19 \mathrm{cB}$ & $0.25 \mathrm{bA}$ & $20.72 \mathrm{aA}$ & $21.13 \mathrm{bB}$ & $0.91 \mathrm{cB}$ & $1.18 \mathrm{bA}$ \\
\hline \multirow[t]{3}{*}{$\mathrm{GSP}+\mathrm{CPR}+\mathrm{BC}$} & $0.28 \mathrm{bA}$ & $0.22 \mathrm{bB}$ & $25.18 \mathrm{bAB}$ & $24.22 \mathrm{aB}$ & $1.11 \mathrm{bA}$ & $0.90 \mathrm{cB}$ \\
\hline & \multicolumn{6}{|c|}{$20-40 \mathrm{~cm}$} \\
\hline & With fire & Without fire & With fire & Without fire & With fire & Without fire \\
\hline GSP & $0.26 \mathrm{abA}$ & $0.09 \mathrm{bB}$ & $19.13 \mathrm{bA}$ & $23.64 \mathrm{bA}$ & $1.35 \mathrm{bA}$ & $0.38 \mathrm{bA}$ \\
\hline $\mathrm{GSP}+\mathrm{BC}$ & $0.24 \mathrm{bA}$ & $0.09 \mathrm{bB}$ & $19.14 \mathrm{bA}$ & $20.35 \mathrm{bA}$ & $1.25 \mathrm{bA}$ & $0.44 \mathrm{~dB}$ \\
\hline $\mathrm{GSP}+\mathrm{CPR}$ & $0.23 \mathrm{bB}$ & $0.36 \mathrm{aA}$ & $23.54 \mathrm{aA}$ & $17.92 \mathrm{cB}$ & $0.97 \mathrm{cB}$ & $2.00 \mathrm{aA}$ \\
\hline $\mathrm{GSP}+\mathrm{CPR}+\mathrm{BC}$ & $0.35 \mathrm{aA}$ & $0.35 \mathrm{aA}$ & $22.34 \mathrm{aB}$ & $29.46 \mathrm{aA}$ & $1.56 \mathrm{aA}$ & $1.18 \mathrm{cdB}$ \\
\hline
\end{tabular}

Means followed by the same lowercase letter in the columns comparing responses to application of organic residues, or uppercase letters in the rows comparing responses to treatments with and without fire, are not different by the Tukey's test at $5 \%$ probability level. GSP $=$ Gliricidia sepium plants; $\mathrm{GSP}+\mathrm{CPR}=G$. sepium plants and carnauba processing residue; $\mathrm{GSP}+\mathrm{BC}=G$. sepium plants and bio-compost; $\mathrm{GSP}+\mathrm{CPR}+\mathrm{BC}=G$. sepium plants, carnauba processing residue, and biocompost (cashew leaves, caprine manure, and carnauba processing residue).

These results differ from those found by Potes et al. (2010), who found higher proportions of more labile fractions of the SOM, mainly POC in environments with use of fire. However, the effect of fire on the compartments of the SOM is variable and dependent on the intensity and recurrence of the use of fire, type of vegetation, soil texture, and climate (VERGNOUX et al., 2011).

Moreover, other studies agree that the resulting charcoal in the soil due to the use of fire would contribute to increases in contents of more recalcitrant soil compartments (STEINER et al., 2012) and decreases in more labile ones, such as POC. This effect was found in the present study, since the treatments showed higher MAOC than POC contents (Table 2), mainly in the surface layers with the use of fire.

The different residues evaluated affected the POC contents, with higher contents in the alleys with $\mathrm{GSP}+\mathrm{CPR}+\mathrm{BC}$ and GSP+CPR (Table 2). The highest $\mathrm{POC}$ contents were found in the treatments $\mathrm{GSP}+\mathrm{CPR}$ in the $0-10 \mathrm{~cm}$ layer, $\mathrm{GSP}+\mathrm{BC}$ in the 10 $20 \mathrm{~cm}$ layer, and GSP+CPR+BC in the $20-40 \mathrm{~cm}$ layer.

POC contents are dependent on carbon contents provided by plant residues. In addition, biocomposts applied in depth (in pits) favor the increase of POC contents in short times (LIMA et al., 2016; BRIEDS et al., 2012). The residues of $G$. sepium plants increased the POC, and the carnauba processing residue contributed to the physical protection of this fraction by adding a ceriferous component to this material. A high carbon accumulation, mainly in the POC, indicates an occurrence of significant addition of biomass (ROSSI et al., 2012), and a high stability of soil aggregates, mainly macroaggregates (HEIDE et al., 2009).

The MAOC contents were higher when using $\mathrm{GSP}+\mathrm{CPR}+\mathrm{BC}$ and $\mathrm{GSP}+\mathrm{CPR}$ (Table 2) with and without the use of fire, in the three soil layers evaluated. The lowest MAOC contents were found when using GSP and GSP+BC. Therefore, the carnauba processing residue increased the contents of more recalcitrant fractions of the SOM and increased POC contents. Studies have shown that this increase caused by a longer time of management with carnauba processing residue, since its decomposition presents different stages due to the protection of ceriferous components, high lignin contents, and large particles, which decrease the biodegradation process and the area available to decomposer agents (KIEHL, 1985; IWATA et al., 2020; SILVA et al., 2020).

The higher MAOC contents indicated more efficient processes of stabilization and humification of the SOM in these alleys. According to Pragana et al. (2012), the formation of organo-mineral complexes indicates a high conservation of total contents of the SOM. Moreover, Carmo et al. (2012) point out that an adequate quantity of POC is essential to ensure the carbon flow and maintenance of biological activity. Therefore, high contents of MAOC are important to ensure the supply to 
microorganisms, the SOM oxidation processes, and the carbon stocks, preventing soil loss and degradation processes.

The POC to MAOC ratio was, in general, higher in the managements without the use of fire, mainly in the $0-20 \mathrm{~cm}$ layer. The POC to MAOC ratio were also affected by the residues (Table 2 ). The highest ratios in the $0-10 \mathrm{~cm}$ layer were found in the treatment GSP without fire, and the lowest in the treatment GSP $+\mathrm{BC}$ without fire. The highest ratios in the $10-20 \mathrm{~cm}$ layer were found in the treatments GSP and $\mathrm{GSP}+\mathrm{BC}$; and in the layer $20-40 \mathrm{~cm}$, the highest ratios were found in the treatments $\mathrm{GSP}+\mathrm{CPR}+\mathrm{BC}$ and GSP+CPR, without fire. POC to MAOC ratio is an indicator of SOM lability, and a high ratio denotes a high proportion of POC, a high lability of the
SOM, and a high supply of substrates for microbial growth and, consequently, release of nutrients to the soil (LOSS et al., 2009; CRUZ, 2020).

The results of the sensitivity index showed that POC was the most sensitive fraction of the MOS to environmental changes (Figure 1). High sensitivity indexes were found for the POC in the soil surface and subsurface in all alleys, regardless of the use of fire.

Moura et al. (2017) evaluated organic matter and carbon management in soils treated with composted residues and laminar composting and found that the SOM fractions were more suitable to differentiate the treatments than the total organic carbon contents.
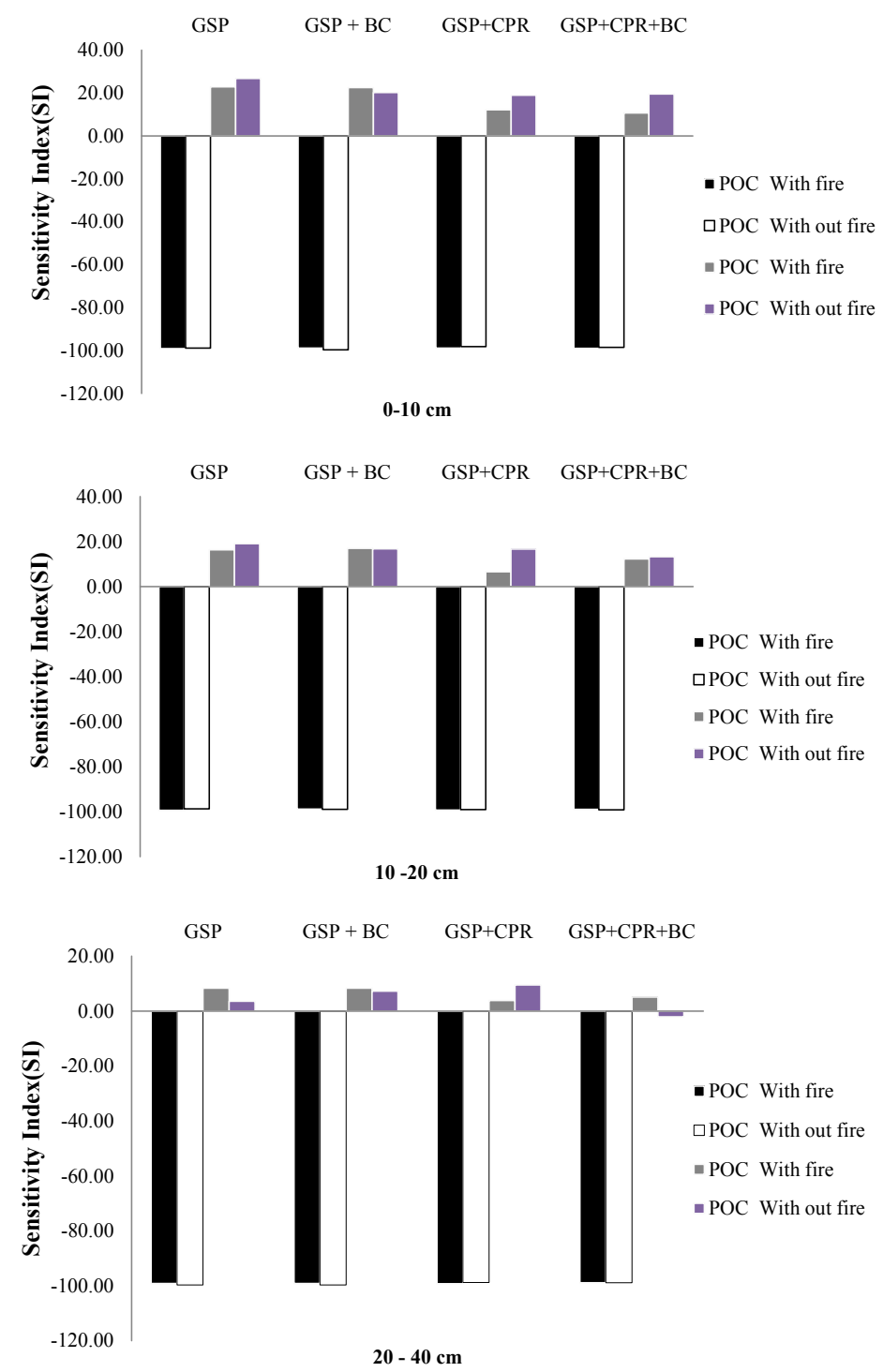

$\mathrm{GSP}=$ Gliricidia sepium plants; $\mathrm{GSP}+\mathrm{CPR}=$ G. sepium plants and carnauba processing residue; $\mathrm{GSP}+\mathrm{BC}=$ G. sepium plants and bio-compost; $\mathrm{GSP}+\mathrm{CPR}+\mathrm{BC}=G$. sepium plants, carnauba processing residue, and bio-compost (cashew leaves, caprine manure, and carnauba processing residue).

Figure 1. Sensitivity index of organic matter fractions in a Typic Hapludult in an agroforestry system managed with organic residues in the Caatinga biome, Brazil. 
The use of fire decreased the soil total organic carbon stocks, mainly in the surface layers (0-10 and $10-20 \mathrm{~cm})$ and, therefore, the recovery capacity of carbon contents over time (VERGNOUX et al., 2011; IWATA et al., 2012; VIEIRA et al., 2016). In addition, it decreased the labile carbon contents and the potential carbon stocks over time. These effects were found after six years of management with the use of fire, despite the current agroforestry management system, with direct addition of SOM.

The use of residues of $G$. sepium plants was efficient in increasing total carbon stocks in alleys in this model of agroforestry system, in the three soil layers (Table 3). Ngome, Becker and Mtei (2011) evaluated the effect of growing leguminous plants in soils of family farms in Africa and found correlation between increases in soil carbon sequestration and the addition of organic content by the biomass of $G$. sepium plants. Thus, carbon stocks increase when using management systems that add high quantities of plant residues to the soil and little soil turning, which increases the soil total organic carbon stock and sequestration. The agroforestry system studied fits to these characteristics (RIBEIRO et al., 2019), due to its high potential for maintenance of total organic carbon stocks, diversity of organic residues, and addition of organic matter with different labilities (Table 3).

Rosa et al. (2019) evaluated the effect of agroforestry systems on the soil physical attributes and the organic carbon stocks in the West region of Bahia, Brazil and found higher distribution of organic matter with different $\mathrm{C}$ to $\mathrm{N}$ ratio in these systems; thus, agroforestry systems combining arboreal species and agricultural crops provide higher carbon increases. In addition, Linhares et al. (2016) stressed that among the land use systems, agroforestry is the one that accumulates the highest active biomass due to the combination of two or more species, which results in a greater potential for soil carbon stocks and conservation of soil intrinsic chemical properties (BARBOSA et al., 2016).

The highest carbon stocks were found in subsurface layers, which may be due to the higher carbon stabilization in deeper layers, due to the lower exposure to biodegradation processes that are more pronounced in surface layers (ROSA et al., 2019). Guo et al. (2020) also found higher carbon contents in subsurface layers when evaluating the carbon vertical distribution in an agroforestry. Couto et al. (2017) attributed the higher carbon stocks in deeper layers to a higher degree of maturity and processing of this carbon by microorganisms.

The complex composition of the agroforestry system evaluated, combining a legume species, crop species, and an arboreous component, with or without addition of organic compounds (residues and bio-compost) promotes qualitative and quantitative increases in different fractions of the SOM and carbon stocks, essential to maintain the soil quality, which is important to the study region, considering that most soils in the Semiarid region of Brazil present very low natural carbon contents. This condition combined with the use of residues with different organic and structural properties allows for a balanced SOM labile and recalcitrant compartments, thus ensuring the increase of the complexity and maintenance of the carbon in the soil (IWATA et al., 2012).

Table 3. Carbon stocks in a Typic Hapludult managed with organic residues, with and without the use of fire, in an agroforestry system in the Caatinga biome, Brazil.

\begin{tabular}{lcccccc}
\hline \multirow{2}{*}{ Treatments } & \multicolumn{5}{c}{ Est C $\left(\mathrm{Mg} \mathrm{ha}^{-1}\right)$} \\
\cline { 2 - 7 } & \multicolumn{2}{c}{$0-10 \mathrm{~cm}$} & \multicolumn{2}{c}{$10-20 \mathrm{~cm}$} & \multicolumn{2}{c}{$20-40 \mathrm{~cm}$} \\
\cline { 2 - 7 } & With fire & Without fire & With fire & Without fire & With fire & Without fire \\
\cline { 2 - 7 } GSP & $1.55 \mathrm{abB}$ & $1.60 \mathrm{aA}$ & $3.15 \mathrm{abB}$ & $3.22 \mathrm{aAB}$ & $3.22 \mathrm{aA}$ & $3.07 \mathrm{bB}$ \\
GSP+BC & $1.05 \mathrm{cB}$ & $1.52 \mathrm{bA}$ & $3.07 \mathrm{bB}$ & $3.16 \mathrm{abA}$ & $3.22 \mathrm{aAB}$ & $3.18 \mathrm{abB}$ \\
GSP+CPR & $1.42 \mathrm{bB}$ & $1.50 \mathrm{bA}$ & $2.88 \mathrm{cB}$ & $3.16 \mathrm{abA}$ & $3.08 \mathrm{bB}$ & $3.25 \mathrm{aA}$ \\
GSP+CPR+BC & $1.04 \mathrm{cB}$ & $1.51 \mathrm{bA}$ & $3.04 \mathrm{bcA}$ & $3.07 \mathrm{bA}$ & $3.12 \mathrm{abA}$ & $2.90 \mathrm{cB}$ \\
\hline
\end{tabular}

Means followed by the same lowercase letter in the columns comparing responses to application of organic residues, or uppercase letter letters in the rows comparing responses to treatments with and without fire, are not different by the Tukey's test at $5 \%$ probability level. GSP $=$ Gliricidia sepium plants; GSP $+\mathrm{CPR}=$ G. sepium plants and carnauba processing residue; $\mathrm{GSP}+\mathrm{BC}=G$. sepium plants and bio-compost; $\mathrm{GSP}+\mathrm{CPR}+\mathrm{BC}=G$. sepium plants, carnauba processing residue, and bio-compost (cashew leaves, caprine manure, and carnauba processing residue).

Figure 2 shows the significant effect of organic residues and use of fire on the carbon stratification level in the agroforestry system evaluated. The highest stratification levels were found in the treatment $\mathrm{GSP}+\mathrm{CPR}+\mathrm{BC}$ in the $0-20 \mathrm{~cm}$ layer, and in the treatments GSP+CPR and $\mathrm{GSP}+\mathrm{CPR}+\mathrm{BC}$ in the $20-40 \mathrm{~cm}$ layer. The agroforestry system enabled this stratification by the combined effect of the addition of organic residues and the little soil turning, which results in similar conditions to those found in natural environments (FERREIRA et al., 2012) and in no-tillage system (SÁ; LAL, 2009; FERREIRA et al., 2011). 


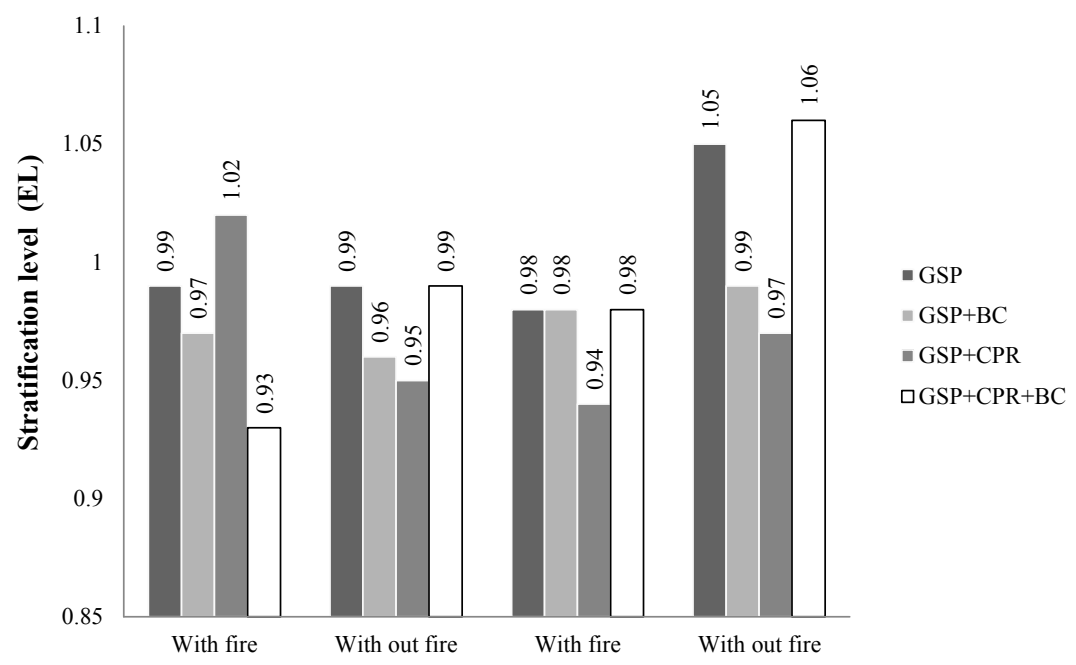

$\mathrm{GSP}=$ Gliricidia sepium plants; $\mathrm{GSP}+\mathrm{CPR}=$ G. sepium plants and carnauba processing residue; $\mathrm{GSP}+\mathrm{BC}=$ G. sepium plants and bio-compost; $\mathrm{GSP}+\mathrm{CPR}+\mathrm{BC}=G$. sepium plants, carnauba processing residue, and bio-compost (cashew leaves, caprine manure, and carnauba processing residue).

Figure 2. Stratification level of total organic carbon in a Typic Hapludult with addition of organic residues, with and without the use of fire, in an agroforestry system in the Caatinga biome, Brazil.

Loss et al. (2009) found a correlation between high stratification levels and the effect of maintaining plant residues on the soil surface combined with little or no soil turning, and highlighted the high concentration of roots in surface layers; therefore, the management of the agroforestry system evaluated in the present study meets the structure and dynamics recommended by them. Thus, although the alleys managed without fire presented a higher stratification level, the soil layers presented significant differences in the alleys with the use of fire, reinforcing the variations due to the type and dynamics of the residue, and denoting the occurrence of carbon stratification, even under manages that include the use of fire (MATIAS et al., 2012).

\section{CONCLUSIONS}

The management of the agroforestry system in alleys with the use of fire decreased the particulate carbon contents in the soil surface layer, even after six years of soil preparation with fire. However, the fire increased mineral-associated organic carbon contents.

The alleys managed with the combination of residues of Gliricidia sepium plants, bio-compost, and carnauba processing residue were efficient for the balancing and maintenance of labile and recalcitrant organic matter compartments, and for the carbon stratification throughout the soil profile.

Particulate organic carbon was more sensitive to changes in soil management than total organic matter contents in all alleys; thus, it is a better indicator of soil quality.

\section{ACKNOWLEDGEMENTS}

We would like to thank Profesor João Ambrósio de Araujo Filho (posthumously) for the subsidy in the area of installation of the research project and all his expertise, for the support of Capes as a scholarship of the main author and to BNB for the financing of the research project.

\section{REFERENCES}

ALVARES, C. A. et al. Köppen's climate classification map for Brazil. Meteorologische Zeitschrift, 22: 711-728, 2014.

ARAÚJO, A. D. M. Estoque de carbono em um latossolo amarelo com cronosequência de cultivos sob sistema plantio direto no sudeste paraense. 2019. 37 f. Monografia (Graduação em Engenharia Ambiental e Energias Renováveis) - Universidade Federal Rural da Amazônia, Belém, 2019.

BANGER, K. et al. Soil organic carbono fraction after 16-years of applications os fertilizer and organic manure in a Tipic Rhodalfs in semi-arid tropics. Journal Nutrient Cycling in Agroecosystems, 86: 391-399, 2010.

BARBOSA, J. S. et al. Eletroquímica e carbono orgânico de um cambissolo húmico no Planalto catarinense sob sistema agroflorestal. Revista Scientia Agraria, 17: 49-56, 2016.

BRIEDS, C. et al. Particulate soil organic carbon and stratification ratio increases in response to crop 
residue decomposition under no-till. Revista Brasileira de Ciência do Solo, 36: 1483-1490, 2012.

CAMBARDELlA, C. A.; ELliOTT, E. T. Particulate soil organic matter changes across a grassland cultivation sequence. Soil Science Society of America Journal, 56: 777-783, 1992.

CARMO, F. F. et al. Granulometric fractions of organic matter of a latosol under no-till with grasses. Bioscience Journal, 28: 420-431, 2012.

COUTO, W. H. et al. Carbono, Nitrogênio, Abundância Natural de $\Delta 13 \mathrm{C}$ e $\Delta 15 \mathrm{~N}$ do Solo sob Sistemas Agroflorestais. Floresta e Ambiente, 24: 1 $-8,2017$.

CRUZ, I. V. Emissão de CO2 e qualidade física e química do solo em sistema integrado de produção agropecuária com ovinos. 2020. $96 \mathrm{f}$. Tese (Doutorado em Agronomia: Área de concentração em agricultura) - Faculdade de Ciências Agronômicas da Unesp, Botucatu, 2020.

FERREIRA, A. O. et al. Relação de estratificação como indicador do sequestro de carbono em macroagregados de Latossolo sob plantio direto. Revista Ciência Rural, 42: 645-652, 2012.

FERREIRA, A. O. et al. Variação na resistência tênsil de agregados em função do conteúdo de carbono em dois solos na região dos Campos Gerais. Revista Brasileira de Ciência do Solo, 35: 437-445, 2011.

FERREIRA, G. A. et al. Carbono orgânico e nitrogênio do solo sob alturas de pastejo da Urochloa ruziziensis em sistema agropastoril. Revista de Ciências Agroveterinárias, 18: 352-362, 2019.

FRANZLUEBBERS, A. J. Soil organic matter stratification ratio as an indicator of soil quality. Journal Soil and Tillage Research, 66: 95-106, 2002.

GUO, J. et al. Effects of three cropland afforestation practices on the vertical distribution of soil organic carbon pools and nutrients in eastern China. Global Ecology and Conservation, 22: 1-10, 2020.

HEIDE, D. M. et al. Frações orgânicas e estabilidade dos agregados de um Latossolo Vermelho Distroférrico sob diferentes usos. Revista de Ciências Agrárias, 51: 143-160, 2009.

IWATA, B. F. et al. Sistemas agroflorestais e seus efeitos sobre os atributos químicos em Argissolo Vermelho-Amarelo do cerrado piauiense. Revista Brasileira de Engenharia Agrícola e Ambiental,
16: 730-738, 2012.

IWATA, B. F. et al. Manejo de resíduos em argissolo sob agrofloresta no semiárido cearense. Brazilian Journal of Development. 6: 20702-20716, 2020.

KIEHL, J. E. Fertilizantes orgânicos. 1. Ed. Piracicaba, SP: Agronômica Ceres, 1985. 492 p.

LINHARES, J. M. S. et al. Variabilidade de atributos físico-químicos e dos estoques de carbono orgânico em argissolos vermelho sob sistemas agroflorestais no assentamento Umari sul do amazonas. Revista Geográfica Acadêmica, 10: 93-117, 2016.

LIMA, C. E. P. et al. Compartimentos de carbono orgânico em Latossolo cultivado com hortaliças sob diferentes manejos. Pesquisa Agropecuária Brasileira, 51: 378-387, 2016.

LOSS, A. et al. Frações oxidáveis do carbono orgânico do solo em sistemas de aléias sob Argissolo Vermelho Amarelo. Revista Brasileira de Ciência do Solo, 33: 867-874, 2009.

LUZ, F. B. Indicadores da qualidade do solo em função do uso da terra. 2017. 88 f. Dissertação (Mestrado em Agronomia: Área de concentração Agricultura e Ambiente) - Universidade Federal de Santa Maria, Frederico Westphalen, 2017.

MATIAS, S. S. R. et al. Influência de diferentes sistemas de cultivo nos atributos físicos e no carbono orgânico do solo. Revista Brasileira de Ciências Agrárias, 7: 414-420, 2012.

MENEZES, C. E. G. et al. Organic matter in areas under secondary forests and pasture. Revista CERNE, 23: 283-290, 2017.

MOURA-BUENO, J. M.; DALMOLIN, R. S. D.; MIGUEL, P. Frações do carbono orgânico do solo sob diferentes usos de terra em áreas de agricultura familiar. Revista Brasileira de Agroecologia, 12: 194-201, 2017.

MOURA, J. A. et al. Respiração basal e relação de estratificação em solo cultivado com citros e tratado com resíduos orgânicos no estado de Sergipe. Revista Semina: Ciências Agrárias, 36: 731-746, 2015.

MOURA, J. A. et al. Organic matter and carbon management index of soil treated with composted and non-composted layered residues. Revista Caatinga, 30: 78-86, 2017.

NANZER, M. C. et al. Estoque de carbono orgânico total e fracionamento granulométrico da matéria orgânica em sistemas de uso do solo no Cerrado. 
Revista de Ciências Agroveterinárias, 18: 136145, 2019.

NGOME, A. F. E.; BECKER, M.; MTEI, K. M. Leguminous cover crops differentially affect maize yields in three contrasting soil types of Kakamega, Western Kenya. Journal of Agriculture and Rural Development in the Tropics and Subtropics, 112: $1-10,2011$.

POTES, M. L. et al. Matéria orgânica em Neossolo de altitude: influência do manejo da pastagem na sua composição e teor. Revista Brasileira de Ciência do Solo, 34: 23-32, 2010.

PRAGANA, R. B. et al. Atributos biológicos e dinâmica da matéria orgânica em Latossolos amarelos na região do Cerrado piauiense sob sistema plantio direto. Revista Brasileira de Ciência do Solo, 36: 851-858, 2012.

RIBEIRO, J. M. et al. Fertilidade do solo e estoques de carbono e nitrogênio sob sistemas agroflorestais no Cerrado Mineiro. Revista Ciência Florestal, 29: 913-923, 2019.

ROSA; V. A. et al. Atributos Físicos e Estoque de Carbono em Sistemas Agroflorestais nos Cerrados do Oeste da Bahia. Revista Brasileira de Geografia Física, 12: 2660-2671, 2019.

ROSSI, C. Q. et al. Frações lábeis da matéria orgânica em sistema de cultivo com palha de braquiária e sorgo. Revista Ciência Agronômica, 43: 38-46, 2012

SÁ, J. C. M.; LAL, R. Stratification ratio of soil organic matter pools as an indicator of carbon sequestration in a tillage chronosequence on a Brazilian Oxisol. Journal Soil and Tillage Research, 103: 46-56, 2009.

SILVA, P. V. C. et al. Utilização de indicadores participativos de qualidade do solo em sistemas de produção agrícola familiar. Revista Nativa, 8: 671678, 2020.

STEINER, F. et al. Estoque de carbon orgânico no solo afetado por adubação orgânica e sistemas de culturas no Sul do Brasil. Revista Semina: Ciências Agrárias, 33: 2775-2788, 2012.

VERGNOUX, A. et al. Effects of forest fires on water extractable organic matter and humic substances from Mediterranean soils: UV-vis and fluorescence spectroscopy approaches. Journal Geoderma, 160: 434-443, 2011.
VIEIRA, A. C. et al. Fogo e seus efeitos na qualidade do solo de pastagem. Revista Brasileira de Geografia Física, 9: 1703-1711, 2016.

YEOMANS, J. C.; BREMNER, J. M. A rapid and precise method for routine determination of organic carbon in soil. Journal Communications in Soil Science and Plant Analysis, 19: 1467-1476, 1988. 